Research article

\title{
Structural study of Gilbertiodendron dewevrei mono-dominant forest based on mature individuals in the Masako forest reserve (Tshopo province, Democratic Republic of the Congo)
}

\author{
Francine K. Botelanyele ${ }^{1}$, Patience K. Kahola ${ }^{1}$, Jean-Leon K. Kambale ${ }^{1}$, Nicole S. \\ Assani $^{1}$, Esther I. Yokana ${ }^{1}$, Prosper S.Yangayobo ${ }^{2}$, Honorine N. Habimana ${ }^{2}$, \\ Monizi Mawunu ${ }^{3}$ and Koto-te-Nyiwa $\operatorname{Ngbolua}^{4} *$ \\ ${ }^{1}$ University of Kisangani, Biodiversity monitoring centre, Department of Ecology and Botanical \\ Resources Management, P.O. Box 2012 Kisangani, Democratic Republic of the Congo \\ ${ }^{2}$ University of Kisangani, Faculty of Science, Department of Ecology and Botanical Resources \\ Management, P.O. Box 2012 Kisangani, Democratic Republic of the Congo \\ ${ }^{3}$ Department of Agronomy, College of Uige Polytechnic, University Kimpo Vita, Republic of Angola \\ ${ }^{4}$ University of Kinshasa, Faculty of Science, Department of Biology, Democratic Republic of the Congo \\ *Corresponding Author: jpngbolua@unikin.ac.cd \\ [Accepted: 15 September 2016]
}

\begin{abstract}
The goal of the study is to determine the vegetal composition and structure based on mature trees in the Masako Forest Reserve. A transect was installed in a mono-dominant forest with Gilbertiodendron dewevrei at $5 \mathrm{~km}$ from the guest house. For transect of 2,100 m, we placed a $500 \mathrm{~m}$ perpendicular line to the survey to a plot of 2,500 square meters in a G. dewevrei forest. An inventory was carried out in an area of 3 ha, consisting of 12 plots of $50 \times 50 \mathrm{~m}$. All trees with a diameter equal or greater than $30 \mathrm{~cm}$ were inventoried, and divided into eight size classes according to their dbh (diameter at breast height) dimension: $<40 \mathrm{~cm} ; 40$ to $49.9 \mathrm{~cm} ; 50$ to 59.9 $\mathrm{cm}$; 60 to $69.9 \mathrm{~cm}, 70$ to $79.9 \mathrm{~cm} ; 80$ to $89.9 \mathrm{~cm} ; 90$ to $99.9 \mathrm{~cm}$ and $\geq 100 \mathrm{~cm}$. To facilitate the inventory, the survey plots were divided in two subplots of $1,250 \mathrm{~m}^{2}$. For the entire forest, we found an overall density of 86.3 stems per hectare of which 63.3 stems/ha belonged to $G$. dewevrei. We also found that the basal area for an individual tree was on average $29.5 \mathrm{~m}^{2} \cdot \mathrm{ha}^{-1}$ for the entire forest, and $24.2 \mathrm{~m}^{2} \cdot \mathrm{ha}^{-1}$ for G. dewevrei.
\end{abstract}

Keywords: Mono-dominant forest - Gilbertiodendron dewevrei - Masako Forest Reserve.

[Cite as: Botelanyele FK, Kahola PK, Kambale J-LK, Assani NS, Yokana EI, Yangayobo PS, Habimana HN, Mawunu M \& Ngbolua K-t-N (2016) Structural study of Gilbertiodendron dewevrei mono-dominant forest based on mature individuals in the Masako forest reserve (Tshopo province, Democratic Republic of the Congo). Tropical Plant Research 3(3): 491-500]

\section{INTRODUCTION}

Tropical rainforests are among to the most diverse terrestrial ecosystems of the world (Borah 2016), but they also contain zones which are dominated by a single species (mono-dominant forests). These zones pose a great enigma in tropical ecology. The mono-dominance leads to a change in the vegetal composition of the forest in which sun-loving species dominate (Fonty 2011). The high diversity of tree species, which is characteristic for tropical forests, is as well a permanent source of scientific questions as a strong constraint to improve our knowledge of the functioning of the forest ecosystem. The answers explaining the preservation of this diversity oppose the deterministic or stochastic mechanisms maintaining this high diversity (Blanc et al. 2003). However, in tropical rainforests, there are areas of low diversity too (Richards et al. 1952), where the canopy trees are dominated by one species (Richards et al. 1996). When this species reaches $50 \%$ of the relative diversity, it is considered to be a mono-dominant species (Hart et al. 1989), single-dominant Forest sensu (Connel et al. 1989). 
This is already known and documented in the tropical forests of Asia, where Drybalonopsa romatica (Dipterocarpaceae) is considered a mono-dominant species (Reitsma 1988).

In the Congo basin, Gilbertiodendron dewevrei (De Wild.) J. Leonard forms extensive stands, which, in some cases, are virtually monophyletic (Whitmore 1984, Gerard 1960, Kouob 2009). Unlike heterogeneous forests, interest on the origin and preservation of mono-dominant tropical forests is recent (Toft et al. 2003). It is assumed that the massive and synchronous fruiting, low diaspores predation, tolerance to low light levels, and ecto-mycorrhizal symbiosis would be the basis for the survival of this forest type. Although they only represent a small fraction of the area of tropical forests, mono-dominant stands were described from all around the tropics. These settlements do not conform to the general pattern and it can be assumed that one or more processes controlling diversity have been altered there. Also the understanding of the mechanisms leading to these species imposing their mono-dominance can shed a (negative) light on the processes allowing the coexistence of many species (Gross et al. 2000).

According to McGuire (2007), the structure of a G. dewevrei forest is the result of the impact of the port and the social temperament of this species on the light factor (Louis 1947). Therefore, we decided to approach the problems by focusing on the $G$. dewevrei forest, where changes are easily noticeable, not only because of its wide distribution in the tropical forest, but also because of its great vegetation diversity.

The structural profiles pose a number of problems, which are sometimes difficult to solve, requiring a lot of time and resources (Mabay 1994). This is also the reason why we based our description of the morphological appearance of the forests on the vegetation composition, vertical and horizontal structure of mature individuals $(\mathrm{dbh} \geq 30 \mathrm{~cm})$ in the G. dewevrei mono-dominant forest. As such, given the extent to which inventories were made, we expected to be closer to the physionomical reality, offering one or two structural profiles. This research was motivated by the need to identify the basic data on the structural composition and plant species diversity of the $G$. dewevrei forest, based on mature individuals $(\mathrm{dbh} \geq 30 \mathrm{~cm})$.

\section{METERIALS AND METHODS}

Study site

Our study was performed in the Masako Forest Reserve, which is located about $14 \mathrm{~km}$ northeast from the city of Kisangani (DRC) on the old road towards Buta $\left(0^{\circ} 36^{\prime} 30.4^{\prime \prime} \mathrm{N} 25^{\circ} 15^{\prime} 38.9^{\prime \prime}\right.$ E) at an altitude of about $500 \mathrm{~m}$ (Sonké 1998). It covers an area of about 2,104 ha of which is occupied by primary forest (Northeast) and at least $2 / 3$ by secondary forests (Northwest). The area was visited during three field trips of ten days (March, April and May 2009).

The structure of mature individuals $(\mathrm{dbh} \geq 30 \mathrm{~cm}$ ) and dominant species (depending on the distribution of tree frequencies classes and the diameter structure) are aspects that have been selected to meet our goal: understanding the particular physiological nature of the primary G. dewevrei forest in Masako, as these aspects allow the easy identification of the balanced state of a plant formation.

\section{Location of the transect}

The transect was traced in the Masako monodominant G. dewevrei forest with the main axis directed in a N$\mathrm{S}$ direction and reaching $5 \mathrm{~km}$ from the camp site. The forest area was divided into plots and transects arranged to pass through a series of tributaries to characterize and visualize the key areas in the various topographical conditions (Mboengongo 1999).

\section{Description of the transect}

Along the 2,100 m main axis of the transect, we drew $500 \mathrm{~m}$ long perpendicular lines at $100 \mathrm{~m}$ intervals, giving a total of 12 lines (Fig. 1). Along these lines, random plots were selected to survey for G. dewevrei. Each of these plots measured $50 \times 50 \mathrm{~m}\left(2,500 \mathrm{~m}^{2}\right)$.

\section{Data collection}

All trees with $\mathrm{dbh} \geq 30 \mathrm{~cm}$ were surveyed and their coordinates (x,y) within the plot, their diameters at a height of $1.30 \mathrm{~m}$ above the ground (= breast height [dbh]) were registered.

\section{Data analysis}

The structure diversity is defined by a set of parameters (plant diversity, density, distribution, vertical distribution, etc.) and dimensions in the plots as well as by the relationships that may exist between these 
parameters. The latter were calculated using the model proposed by (Makana 1989, Gillet et al. 1991). Besides of these quantitative analyses, biodiversity indices were also calculated.

\section{Diversity indices}

1. Margalef diversity index $\left(\mathrm{D}_{\mathrm{Mg}}\right)$

This index is calculated by the following formula:

$$
\mathrm{D}_{\mathrm{Mg}}=(\mathrm{S}-1) / \ln (\mathrm{N}) \text {. }
$$

Where, $\mathrm{S}=$ number of species and $\mathrm{N}=$ total number of individuals.

2. Menhinick diversity index $\left(\mathrm{D}_{\mathrm{Mn}}\right)$

This index is calculated as follows:

$$
\mathrm{D}_{\mathrm{Mn}}=\mathrm{S} / \sqrt{\mathrm{N}}
$$

Where, $\mathrm{S}=$ number of species, $\mathrm{N}=$ total number of individuals.

3. Simpson diversity index $\left(\mathrm{D}_{\mathrm{S}}\right)$

This index measures the probability that two individuals, that were selected by chance, belong to the same species:

$$
\mathrm{D}_{\mathrm{S}}=\Sigma \mathrm{p}_{\mathrm{i}}^{2} \quad \text { with } \mathrm{p}_{\mathrm{i}}=\mathrm{n}_{\mathrm{i}} / \mathrm{N}
$$

Where, $\mathrm{n}_{\mathrm{i}}=$ number of individuals belonging to a given species $\mathrm{i}, \mathrm{N}=$ total number of individuals.

4. Shannon-Wiener diversity index

According to Lejoly (1993) and Danais (1982), the Shannon-Wiener index measures the average amount of information presented by the indication of the species of an individual to the collection.

$$
\mathrm{H}^{\prime}=-\Sigma\left(\mathrm{p}_{\mathrm{i}} \ln \mathrm{p}_{\mathrm{i}}\right) \quad \text { with } \mathrm{p}_{\mathrm{i}}=\mathrm{n}_{\mathrm{i}} / \mathrm{N}
$$

Where, $\mathrm{N}=$ total number of individuals (i.e. trunks), $\mathrm{n}_{\mathrm{i}}=$ number of individuals belonging to a given species $\mathrm{i}$ (between 0 and $\mathrm{N}$ ), $\mathrm{p}_{\mathrm{i}}$ ranges from 0 to $1 . \mathrm{S}$

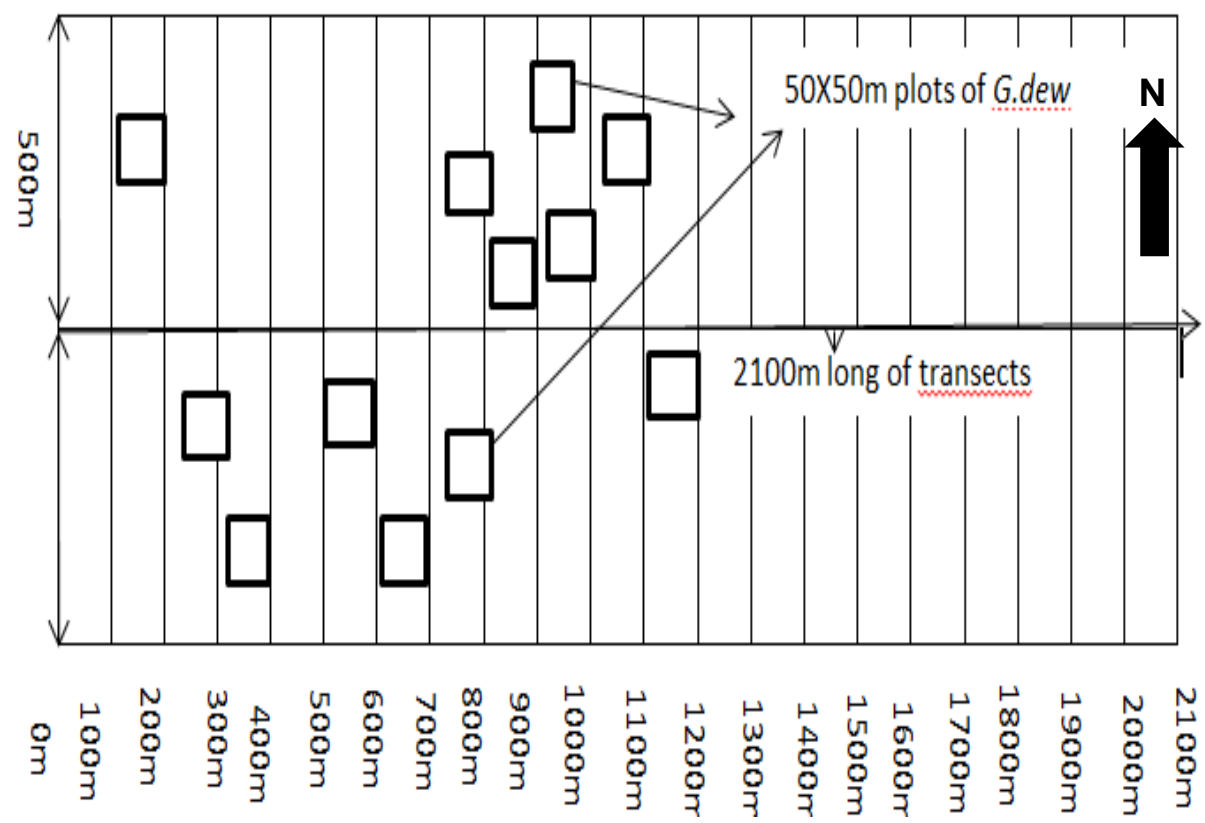

Figure 1. Schematic representation of the sampling plots in the Masako Gilbertiodendron dewevrei mono-dominant forest.

Variation Coefficient (VC)

This coefficient is used to compare two standard deviations, especially when the means are different. It also allows us to evaluate the magnitude of dispersion of data. The high value of VC indicates the larger of the dispersion around the mean (Frontier 1993, Legendre et al. 1998).

$$
\mathrm{VC}={ }^{\delta} \times 100 / \mathrm{M}
$$

Where, ${ }^{\delta}$ - variance, $\mathrm{M}$ - mean

If $\mathrm{VC}<15 \%$, the dispersion is low or less pronounced and the series is homogeneous. If $\mathrm{VC}$ is between $15 \%$ and $30 \%$, the dispersion is somewhat weak and the series is relatively homogeneous, However, if VC > $30 \%$, the dispersion is most pronounced or high and the distribution is heterogeneous. 


\section{Diametric and structural analysis}

The total diametric structure or distribution of stems per diameter class is determined by taking into account the individuals of every species (Magurran 2004). This value gives information on the stability of the stands. It can also be calculated for specific species and in that case, it represents the specific structure. The diametric structure indicates the number of stems inventoried by diameter classes. The Cartesian coordinates ( $\mathrm{x}, \mathrm{y})$ of all individuals Gilbertiodendron dewevrei (with $\mathrm{dbh} \geq 30 \mathrm{~cm}$ ) were registered to accurately characterize the organization of the trees in each plot. The basal area is expressed in $\mathrm{m}^{2}$ (Rollet 1974) is calculated for each individual by means of the formula $\mathrm{ST}=\pi \mathrm{D}^{2} / 4$ where $\mathrm{D}$ is the $\mathrm{dbh}$.

\section{Quantitative study}

Quantitative determination of the data results in their structural nature consisting of a set of parameters, including the spatial distribution, species density and the relationships that interfere with these (Gounot 1969). The abundance or relative density of a species and a family is calculated as the total number of individuals of a species or family in the sample multiplied by 100 :

$$
\mathrm{RD}_{\mathrm{s}}=\left(\mathrm{n}_{\mathrm{s}} / \mathrm{N}\right) \times 100
$$

Where, $\mathrm{n}_{\mathrm{s}}$ is the number of individuals for a given species and $\mathrm{N}$ is the total number of individuals in the sample.

$$
\mathrm{RD}_{\mathrm{f}}=\left(\mathrm{n}_{\mathrm{f}} / \mathrm{N}\right) \times 100
$$

Where, $\mathrm{n}_{\mathrm{f}}$ is the number of individuals for a given family and $\mathrm{N}$ is the total number of individuals in the sample.

The relative dominance of a species or family is determined by the basal area occupied by a species or family in total basal area and is multiplied by 100 according to following formula:

$$
\int \mathrm{t}_{\mathrm{s}} / \int \mathrm{s}_{\mathrm{t}} \times 100
$$

and for the family $\int \mathrm{t}_{\mathrm{f}} / \int \mathrm{s}_{\mathrm{t}} \times 100$

Where, $\int \mathrm{t}_{\mathrm{s}}$ is the basal area of a species, $\int \mathrm{t}_{\mathrm{f}}$ the basal area of a family and $\int \mathrm{S}_{\mathrm{t}}$ the total basal area in the sample

\section{Density}

Density is defined as the number of stems per surface unit. There are several expressions of density. However, the most commonly used is the number of stems per hectare (N/ha). Unfortunately, this expression of the density does not take into account the size of trees.

\section{RESULTS AND DISCUSSION}

Vegetation composition and density

The floristic study in the Masako G. dewevrei mono-dominant forest resulted in an overall number of 259 individuals with $\mathrm{dbh} \geq 30 \mathrm{~cm}$, divided over 36 species, 34 genera, 19 families (Fig. 2).

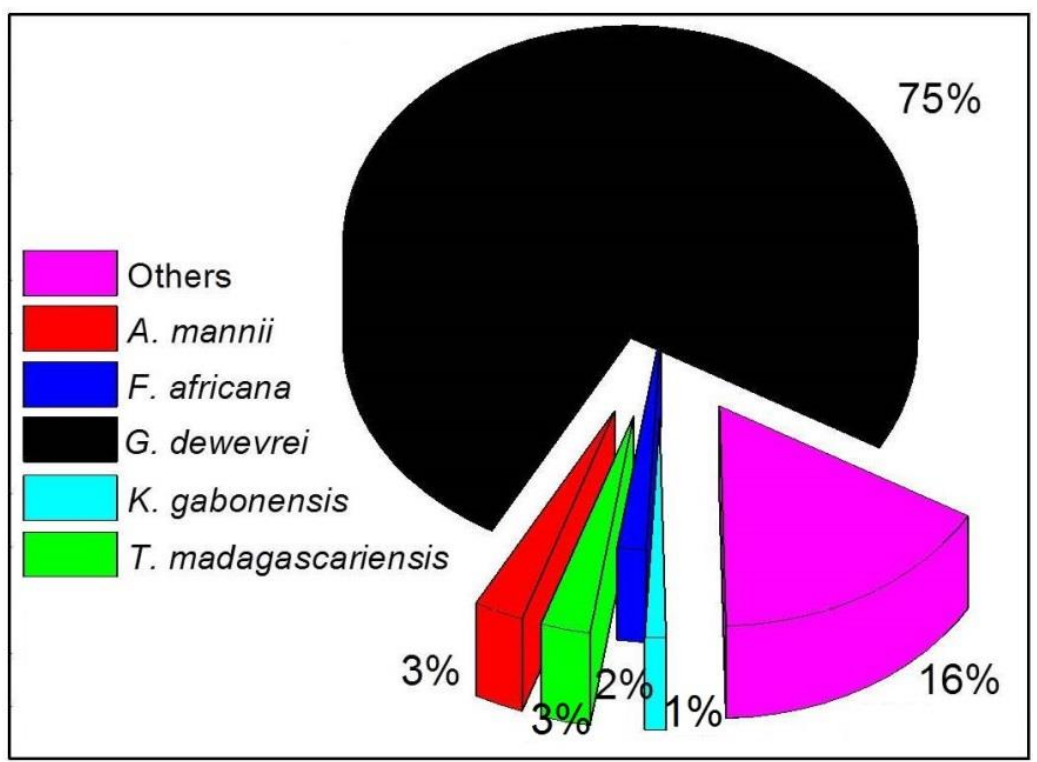

Figure 2. Floristic composition of Gilbertiodendron dewevrei mono-dominant forest at the Masako Forest Reserve. 
The Gilbertiodendron dewevrei dominate the sample with $75 \%$, followed by the Anonidium mannii and Trilepisium madagascariensis with $3 \%$ each, followed by the Funtumia africana with $2 \%$, Klainedoxa gabonensis (1\%) and other species are each represented with $16 \%$.
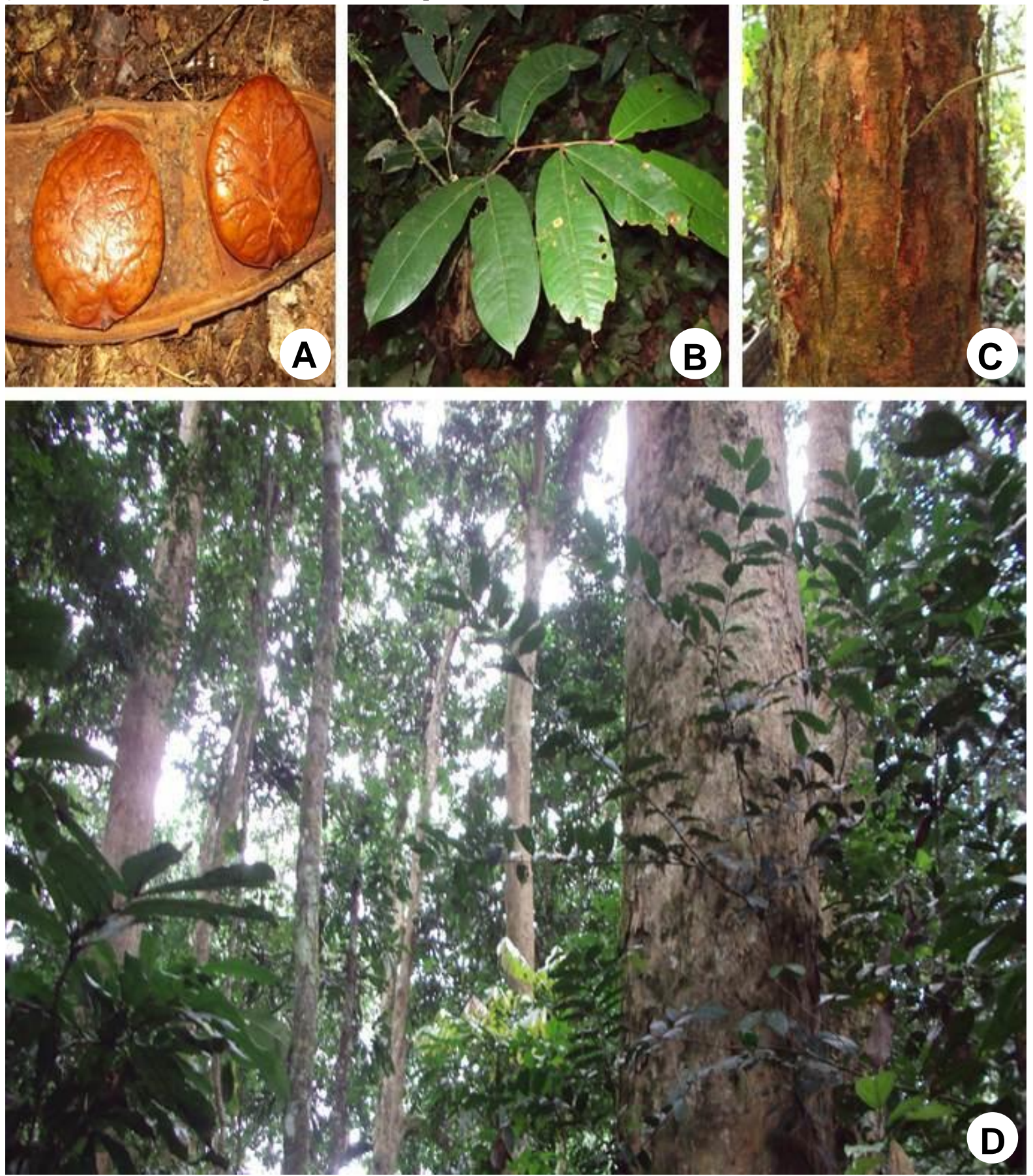

Figure 3. Gilbertiodendron dewevrei (De Wild.) J.Leonard: A, Seeds; B, Seedling; C, Stem with bark; D, Habitat.

Stocking densities of individuals in the Masako G. dewevrei mono-dominant forest

The 3 ha sample area in the Masako $G$. dewevrei mono-dominant forest contained 259 trees with dbh $\geq 30$ $\mathrm{cm}$. On average, there were 86.3 trees per ha. Of these trees, 190 belonged to $G$. dewevrei, giving an average per hectare of 63.3 .

Quantitative analysis of the floral data

The global basal areas for the Masako G. dewevrei mono-dominant forest is $29.5 \mathrm{~m}^{2} / \mathrm{ha}$ and $24.2 \mathrm{~m}^{2} / \mathrm{ha}$ for G. dewevrei individuals.

The species abundance in the G. dewevrei mono-dominant forest at Masako 
The current study indicates that the dominant species at Masako are: Gilbertiodendron dewevrei, Musanga cecropioides, Anonidium mannii, Trilepisium madagascariensis, Funtumia africana, Klainedoxa gabonensis, Petersianthus macrocarpus and Panda oleosa (Fig. 3).

Vegetation structure by diametric class

The diameter distribution of all species combined (total structure) is one of the stand's characteristics reflecting an equilibrium constant, which is the existence wherever moist evergreen forests are in their original state (Fournier et al. 1983). To highlight the disturbed state of forest plant community proposed a structural analysis for the species that account for the unbalanced or balanced state of the forest.

\section{Diversity indices}

The alpha $(\alpha)$ diversity was calculated using the following indices: Shannon-Wiener, Menhinick, Margalef and Simpson. This allows assessing the diversity of each group, according to the species distribution, more accurately. Margalev index gives the highest value (6.299). This shows that the Masako G. dewevrei monodominant forest is more diverse in species.

It has a good evenness between the species studied. This demonstrates the dominance of the G. dewevrei forest on others in terms of species richness. The Simpson index, meanwhile, shows that the diversity of sites is not so variable because the value obtained (0.458) represents a very low diversity. On the other hand, the Menhinick index, which is based on species richness, presents a distinctly lower value (2.237) relative to Margalef index, where the number of individuals is relatively low. Comparing the Menhinick index with the one from Margalef reveals that both indices almost evolve in the same way.

There is a minor difference at the species level, where the Margalef index results in higher values if there is a higher number of individuals, while that of Menhinick is low. In the current study, the Shannon index is relatively low as it represents the sum of the information given by the frequency of the various species over the 3 ha sampled surface.

\section{Statistical parameters}

The data for the $G$. dewevrei trees occurring in the twelve $50 \times 50 \mathrm{~m}$ sample plots of the Masako Gilbertiodendron dewevrei dominated forest are presented in tables 1 and 2.

Table 1. Number of Gilbertiodendron dewevrei trees with $\mathrm{dbh} \geq 30 \mathrm{~cm}$ and distribution of diameter registered in the twelve $50 \times 50 \mathrm{~m}$ sample plots.

\begin{tabular}{cccc}
\hline Sample plot & Number of trees & Diametric Class & Number of trees \\
\hline P1 & 14 & $30-39,9$ & 31 \\
P2 & 16 & $40-49,9$ & 25 \\
P3 & 16 & $50-59,9$ & 28 \\
P4 & 12 & $60-69,9$ & 30 \\
P5 & 21 & $70-79,9$ & 35 \\
P6 & 23 & $80-89,9$ & 13 \\
P7 & 17 & $90-99,9$ & 10 \\
P8 & 17 & $\geq 100$ & 190 \\
P9 & 17 & Total & 23,75 \\
P10 & 12 & Moyenne & 82,21 \\
P11 & 17 & Variance & 9,06 \\
P12 & 8 & Ecart-type & 38,14 \\
Total & 190 & CV $(\%)$ & \\
Average & 15,8 & & \\
Variance & 16,15 & & \\
Standard deviation & 4,01 & & \\
CV(\%) & 25,37 & & \\
\hline
\end{tabular}

The average number of $G$. dewevrei trees over the sampled plots is 15.8 (Table 1). The values for the individual sample plots are more or less around this average value, with one lower value for P12 and two higher ones for P5 and P6. The coefficient variation is between 15 and 30\% indicating that the dispersion is somewhat weak. The distribution of individuals in the different plots is considered relatively homogeneous. This indicates that on average, there are $23.7 \mathrm{G}$. dewevrei trees in each diametric class. However, in most of the diametric classes the number of trees differs considerably from that average. The coefficient variation exceeds $30 \%$, 
indicating that the dispersion is strong and that the diametric distribution of $G$. dewevrei should be considered heterogeneous.

Over the 12 sampled plots, there were on average 21.6 trees with $\mathrm{dbh} \geq 30 \mathrm{~cm}$. The low value registered for P12 confirms the low value for G. dewevrei trees. This is also the case for the high values in P5 and P6, although these are less extreme than found for $G$. dewevrei. The coefficient variation is low (less than $15 \%$ ), indicating that the plots form a homogenous sample.

Table 2 shows that in the G. dewevrei forest, there were on average 32.4 trees in each of the diametric classes. With the exception of classes 50 to $79.9 \mathrm{~cm}$, most classes have a value which is quite different from the average value. As was already shown in figure 4 the smaller classes have a much higher number of trees, and the larger classes have a much lower number. The tree class of $\geq 100 \mathrm{~cm}$ contains an elevated number of trees, which might be explained as being the result of including a much wider range of diameters, with trees up to 136, $6 \mathrm{~cm}$ the coefficient variation exceeds $30 \%$, confirming the heterogeneity of the sampled plots in relation to the diameter of the trees.

Table 2. Number of trees with $\mathrm{dbh} \geq 30 \mathrm{~cm}$ and diameter distribution registered in the twelve $50 \times 50 \mathrm{~m}$ sample plots.

\begin{tabular}{cccc}
\hline Sample plot & Number of trees & Diametric Class & Number of trees \\
\hline P1 & 22 & $30-39,9$ & 65 \\
P2 & 23 & $40-49,9$ & 40 \\
P3 & 20 & $50-59,9$ & 35 \\
P4 & 23 & $60-69,9$ & 33 \\
P5 & 24 & $70-79,9$ & 35 \\
P6 & 26 & $80-89,9$ & 18 \\
P7 & 19 & $90-99,9$ & 10 \\
P8 & 21 & $\geq 100$ & 23 \\
P9 & 19 & Total & 259 \\
P10 & 21 & Moyenne & 32,375 \\
P11 & 23 & Variance & 124,07 \\
P12 & 18 & Ecart-type & 11,13 \\
Total & CV $(\%)$ & 34,37 \\
Average & 259 & & \\
Variance & 21,58 & & \\
Standard deviation & 5,53 & & \\
CV(\%) & 2,35 & & \\
\hline
\end{tabular}

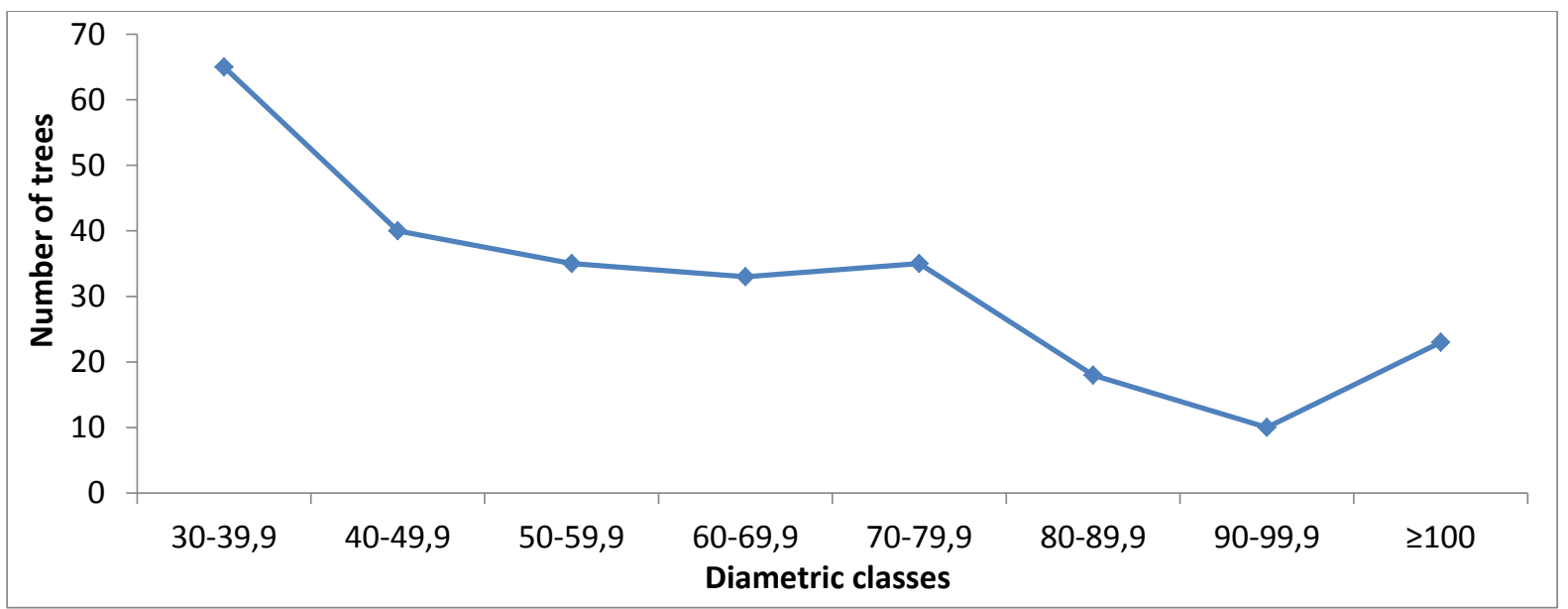

Figure 4. Vegetation structure by diametric class at Masako forest reserve.

The present study revealed that the sample area ( 3 ha) in the Masako G. dewevrei mono-dominant forest contained 259 trees with $\mathrm{dbh} \geq 30 \mathrm{~cm}$. On average, there were 86.3 trees per ha. Of these trees, 190 belonged to G. dewevrei, giving an average per hectare of 63.3. Lomba (2007), working in the G. dewevrei monodominant forest at Yoko, found 97 trees with $\mathrm{dbh} \geq 30 \mathrm{~cm}$ in a 3 ha plot, resulting in an average of 32.3 threes per ha. 74 of the trees belonged to G. dewevrei (or $24.7 \mathrm{ha}^{-1}$ ). These numbers indicate that at Yoko fewer mature trees were occurring, both for all species combined and for $G$. dewevrei separately. This is mainly due to human action as farmers harvest the average diameter $(\leq 40 \mathrm{dbh})$ of species for commercial interests. 
Quantitative analysis of the floral data revealed that the global basal areas for the Masako G. dewevrei monodominant forest is $29.5 \mathrm{~m}^{2} \cdot \mathrm{ha}^{-1}$ and $24.2 \mathrm{~m}^{2} . \mathrm{ha}^{-1}$ for $\mathrm{G}$. dewevrei individuals. For the Yoko forest, Masiala (2009) calculated these as $24.4 \mathrm{~m}^{2} \cdot \mathrm{ha}^{-1}$ and $22.7 \mathrm{~m}^{2} \cdot \mathrm{ha}^{-1}$, respectively. This allows us to hypothesise that the forest at Yoko is still evolving and that this is no longer the case for the forest at Masako, which also has a much more disturbed character.

By comparing the species abundance in the G. dewevrei mono-dominant forest at Masako with the work of other researchers, the current study indicates that the dominant species at Masako are: Gilbertiodendron dewevrei, Musanga cecropioides, Anonidium mannii, Trilepisium madagascariensis, Funtumia africana, Klainedoxa gabonensis, Petersianthus macrocarpus and Panda oleosa. At Yoko, Masiala (2009) found the dominant species to be: Gilbertiodendron dewevrei followed by Scorodophloeus zenkeri, Julbernardia seretii, Gilbertiodendron kisantuensis and Grossera sp. In the forest of Uma, Katembo (2013) found that the dominant species are: Gilbertiodendron dewevrei (29\%), followed by Cola griseiflora (8\%), Diospiros sp (6\%) and other species. The species composition varies from site to site.

In the three sites (Masako, Yoko and Uma) the same trend in abundance of Gilbertiodendron dewevrei was encountered. However, in the two following locations, this was not the case. Indeed, in Mbiye Island, Kambale (2009) found that Coelocaryon botryoides was the most abundant species, followed by Gilbertiodendron dewevrei, Diospyros boala, Pycnanthus angolensis and Cleistanthus mildbraedii.

The diameter distribution of all species combined (total structure) is one of the stand's characteristics reflecting an equilibrium constant, which is the existence wherever moist evergreen forests are in their original state (Fournier et al 1983). To highlight the disturbed state of forest plant community proposed a structural analysis for the species that account for the unbalanced or balanced state of the forest.

Nshimba (2008) indicated that Gilbertiodendron dewevrei forest at Uma and the mixed forest on the Mbiye Island have the form of a "mirrored $\mathrm{J}$ " for the stems with $\mathrm{dbh} \geq 30 \mathrm{~cm}$, whereby the class size $30-39.9 \mathrm{~cm}$ accounts for the highest number of trees and subsequent diametric classes all have lower values. These forests have the typical diametric structure of natural forests, which is contrary to the Masako Gilbertiodendron dewevrei.

Forest showing that the histogram has the form of a "mirrored $\mathrm{J}$ with a bulbous tail". The diametric classes between 40 and $70 \mathrm{~cm}$ dbh contain much higher numbers of trees, which indicate that the Masako forest is unbalanced and this is due to human action. Farmers harvest the average diameter of species for commercial interests.

\section{CONCLUSION}

The current study has focused on the forest structure of a Gilbertiodendron dewevrei monodominant forest based on tree species in the Masako Forest Reserve. An inventory of the mature trees $(\mathrm{dbh} \geq 30 \mathrm{~cm})$ was made on a 3 ha area, which was composed of 12 plots of $50 \times 50 \mathrm{~m}$ each, where all trees meeting this condition were surveyed.

- In the 3 ha sample area, 259 meeting the dbh condition were registered. The number of trees is 259 for the forest $G$. dewevrei in 3 ha. Trees belonging to the Fabaceae family were found to be the most commonly occurring group ( $85 \%$ of species).

○ The results showed that the overall tree density is 83.3 stems/ha and $63.3 \mathrm{stems} / \mathrm{ha}$ for G. dewevrei.

○ In the forest, the overall basal area is $29.5 \mathrm{~m}^{2} \cdot \mathrm{ha}^{-1}$ and for G. dewevrei this is $24.2 \mathrm{~m}^{2} \cdot \mathrm{ha}^{-1}$.

○ The vegetation was classified in eight diameter classes: $3039.9 \mathrm{~cm} ; 40-49.9 \mathrm{~cm} ; 50-59.9 \mathrm{~cm}$; 60-69.9 cm; $70-79.9 \mathrm{~cm} ; 80-89.9 \mathrm{~cm}$; 90-99.9 $\mathrm{cm}$ and $\geq 100 \mathrm{~cm}$.

- As illustrated by the high values for the variance coefficient (exceeding 30\%), the diametric distribution is heterogeneous for both the overall sample and G. dewevrei alone.

Regarding the distribution of the number of trees over the sampled plots, the variation coefficient has values between 15 and $30 \%$, indicating that the forest is relatively homogeneous. Additional research is needed to find ways to stop the decrease and to determine measures enabling to prevent the forest overexploitation.

\section{REFERENCES}

Blanc L, Flores O, Molino J-F, Gourlet-Fleury S \& Sabatier D (2003) Diversité spécifique et Regroupement 
d'espèces arborescentes en forêt guyanaise. In Engref, (eds) Revue Forestière française, Nancy. Numéro spécial. connaissance et gestion de la forêt guyanaise, 131-146p.

Borah N, Rabha D \& Athokpam FD (2016) Tree species diversity in tropical forests of Barak valley in Assam, India. Tropical Plant Research 3(1): 1-9.

Connel JH \& Lowman M D (1989) Low-diversity tropical rain forests: some possible Mechanisms for their existence. The American Naturalist 134: 88-119.

Danais M (1982) La diversité écologique: analyse bibliographique. Botanica Rhedonica 17: 77-104.

Frontier S \& Pichod-Viale D (1993) Ecosystème: structure, fonctionnement, Évolution. Collection d'écologie 21, Masson paris, $2 \grave{e}$ édit. $447 \mathrm{p}$.

Fonty E (2011) Etude de l'écologie du Spirotropis longifolia DC Baill. (Leguminosae- Papilionoideae) Espèce monodominante dans les forêts de Guyane française, Ph. D. Thèsis. Université Montpellier II. Sciences Techniques, $209 \mathrm{p}$.

Fournier F \& Sasson A (1983) Les Ecosystèmes forestiers tropicaux d'Afrique. Paris, 473 p.

Gérard $\mathrm{Ph}$ (1960) Etude écologique de la forêt dense à Gilbertiodendron dewevrei dans la région de l'Uélé. 159 p.

Gross ND, Torti SD, Feener DH \& Coley PD (2000) Monodominance in an African Rain Forest: Is Reduced Herbivory Important?. Biotropica 32(3): 430-439.

Gillet F, Foucault B \& Julve P (1991) La phyto-sociologie synusiale intégrée: objets et concepts. Candollea 46: 315-340.

Gounot M (1969) Methodes d'etude quantitative de la végétation. Masson et Cie, 25 p.

Hart TB, Hart JA \& Murphy PG (1989) Monodominant and species-rich forests of the humid tropics: causes for their co-occurrence. The American Naturalist 133: 613-633.

Katembo E (2013) Etude floristique et structurale des forêts monodominantes à Gilbertiodendron dewevrei (Dewild.) J. Léonard, sur terre ferme et sur sol hydromorphe à Uma (Province Orientale) DES/DEA. Faculté des Sciences, Université de Kisangani, 63 p.

Kouob BS (2009) Organisation de la diversité végétale dans les forêts matures de terre ferme du Sud-Est Cameroun, Ph. D. Thesis. Ecole Facultaire du Bio-ingénieur. Université Libre de Bruxelles, 212 p.

Kambale K (2009) Caractéristique floristique de la zone de contact entre la forêt à Gilbertiodendron dewevrei de la forêt mixte de l'ile Mbiye, Mémoire. Faculté des Sciences, Université de Kisangani, 33 p.

Lomba B (2007) Contribution à l'étude de la phytodiversité de la Reserve Forestière de Yoko (Ubundu, R.D. Congo), Mémoire de DES. Faculté des Sciences, Université de Kisangani, 72 p.

Louis J (1947) Contribution à l'étude des forêts équatoriales congolaises. C.R.Sem. Agr. De Yangambi, INEC. Publ., Hors-Série, pp. 902-924.

Lejoly J (1993) Méthodologie ECOFAC pour les inventaires forestiers (Partie flore et végétation). Lab. Bot. Syst. Phyt. Université Libre de Bruxelles, 136 p.

Legendre P \& Legendre L (1998) Numerical Ecology. Developments in Environmental Modelling, Elsevier Science BV, Amsterdam, $853 \mathrm{p}$.

Masiala G (2009) Analyse d'une zone de contact de la forêt à Gilbertiodendron dewevrei (De Wild.) J. Léonard avec la forêt semi-caducifoliée dans la réserve de la Yoko nord 47 (RDC). Mémoire inédit de DES, Faculté de sciences, Université de Kisangani, 103 p.

Mabay K (1994) Contribution à l'étude structurale de forêts primaire et secondaire de la réserve forestière de Masako. Mémoire Faculté des Sciences, Université de Kisangani, 65 p.

Makana M (1989) Contribution à l'étude floristique et écologique de la forêt à Gilbertiodendron dewevrei de la réserve forestière de Masako. Mémoire, Faculté des Sciences, Université de Kisangani, 64 p.

McGuire KL (2007) Ectomycorrhizal networks may maintain monodominance in a tropical rainforest. Ecology 88(3): 567-574.

Mboengongo F (1999) Contribution à l'étude écologique et systématique de champignons supérieurs (Macromycètes) de la Reserve Forestière de Masako à Kisangani (RD Congo). Mémoire, Faculté de Sciences, Université de Kisangani, 85 p.

Magurran AE (2004) Measuring biological diversity. Blackwell Publishing Company, UK, 256 p.

Nshimba S (2008) Etude Floristique, Ecologique et Phytosociologique des Forêts de l'ile Mbiye à Kisangani, RD Congo, Ph. D. Thesis. Faculté des Sciences, Université Libre de Bruxelles. 
Richards PW (1952) The tropical rain forest. Cambridge University, United Press, Cambridge, UK, 25 p.

Richard P (1996) The Tropical Rain forest, An ecological study, $2^{\text {nd }}$ edition, Purseglove, J.W. 1975. Raffia palms. In: ELBS and Longman (ed.), Tropical monocotyledons. Volumes 1 and 2 combined. Cambridge University Press, Cambridge, $440 \mathrm{p}$.

Reitsma TM (1988) Végétation forestière du Gabon, Tropenbos Technical series 1. Netherlands Wageningen, 142 p. Réserve de Biosphère de Luki, Bas-Congo, R.D. Congo, DEA, Inédit, Université de Kisangani, 127 p.

Rollet B (1974) L'architecture des forêts denses humides sempervirentes de plaine. CTFT, Nogent-sur-Marne, France, $115 \mathrm{p}$.

Sonké B (1998) Etudes floristiques et structurales des forêts de la Réserve de Faune du Dja (Cameroun), Thèse de doctorat. Université libre de Bruxelles, $276 \mathrm{p}$.

Toft CA \& Fraizer T (2003) Spatial dispersion and density dependence in a perennial desert shrub (Chrysothamnus nauseosus: Asteraceae). Ecological Monographs 73: 605-624.

Whitmore TC (1984) Tropical rainforest of the far East, $2^{\text {nd }}$ edition. Toronto, Oxford University Press, 282 p. 